\title{
Reproductive biology of the commercial sea cucumber Holothuria spinifera (Echinodermata: Holothuroidea) from Tuticorin, Tamil Nadu, India
}

\author{
P. S. Asha $\cdot$ P. Muthiah
}

Received: 13 September 2006/Accepted: 5 October 2007/Published online: 27 October 2007

(C) Springer Science+Business Media B.V. 2007

\begin{abstract}
The annual reproductive cycle of the commercial sea cucumber Holothuria spinifera was studied in Tuticorin, Tamil Nadu, India, from September 2000 to October 2001, by macroscopic and microscopic examination of gonad tubule, gonad index and histology of gametogenic stages, to determine the spawning pattern. The gonad consists of long tubules with uniform development. It does not confirm the progressive tubule recruitment model described for other holothurians. The maximum percentage of mature animals, gonad and fecundity indices, tubule length and diameter, with the observations on gonad histology, ascertained that $H$. spinifera had the peak gametogenic activity during September and October 2001 followed by a prolonged spawning period from November 2000-March 2001.
\end{abstract}

Keywords Gonad index · Holothuria spinifera $\cdot$ Reproductive cycle · Spawning period

\section{Introduction}

Sea cucumbers form an important part of multispecies fisheries, existing for over 1,000 years along the Indo-Pacific region, and the processed product, the 'beche-de-mer', is a valuable source of income for fishermen. Increasing demand and inadequate management of sea cucumber stocks in many countries have resulted in severe overexploitation of commercially important species (Conand 1997). Sea-ranching, the release of hatcheryproduced juveniles into the natural habitat, is being carried out to restore and enhance the wild stocks for sustainable yield (Yanagisawa 1998). The sea ranching programmes need information on the reproductive biology, ecology and reproductive cycle of the commercial species in order to design breeding programmes (Reichenbach 1999; Herrero Perezrul et al. 1999; Ramofafia et al. 2000).

P. S. Asha $(\bowtie) \cdot$ P. Muthiah

Tuticorin Research Centre of Central Marine Fisheries Research Institute, South Beach Road, Karapad, Tuticorin, Tamil Nadu 628 001, India

e-mail: ashasanil@yahoo.com 
In India, the 'beche-de-mer' industry mainly depends on Holothuria scabra and Holothuria spinifera (Chellaram et al. 2003). According to the statistics of Marine Product Development Authority (MPEDA), Government of India, beche-de-mer exports, which rank first among the dried marine products sold, has declined from $70 \mathrm{t}$ in 1996-97 to $3.8 \mathrm{t}$ in 2001 (MPEDA 1998, 2003). Due to overexploitation, the Ministry of Environment, Government of India, banned both the fishery and export of sea cucumbers from 2001 onwards. $H$. spinifera is a medium valued and widely exploited sea cucumber species in India. James and Badrudeen (1997) estimated annual landings of $460 \mathrm{t}$ of fresh $H$. spinifera along the southeast coast of India. Apart from the Gulf of Mannar and Palk Bay of the Indian coast, $H$. spinifera is reported to occur in the Red Sea, Persian Gulf, Sri Lanka, northern Australia, Philippines and China (James 1995). Considering the role of H. spinifera in the commercial fishery and understanding the reproductive biology of this species is important for hatchery production of juveniles for captive or wild stock enhancement programmes. Since there is a paucity of information on the reproductive biology of $H$. spinifera, the present study was conducted.

\section{Materials and methods}

From September 2000 to October 2001, a total of 294 H. spinifera were collected from the commercial catch of trawlers, which operated at a depth of 10-15 m off Tuticorin in the vicinity of Koswari $\left(78^{\circ} 12^{\prime} 14^{\prime \prime} \mathrm{E}, 8^{\circ} 51^{\prime} 52^{\prime \prime} \mathrm{N}\right)$ and Van Island $\left(78^{\circ} 12^{\prime} 13^{\prime \prime} \mathrm{E}, 8^{\circ} 49^{\prime} 50^{\prime \prime} \mathrm{N}\right)$. Monthly, 18-25 specimens of length ranging from 110 to $403 \mathrm{~mm}$ were brought to the laboratory and kept in seawater prior to dissection and completion of gonadal analysis on the same day.

The total length of the animal, the total weight, drained weight, gonad weight, and gutted or eviscerated weight were recorded following the methods of Conand (1981). The five stages of maturity were based on tubule length, diameter, tubule branching, presence of saccules, colour and the presence of gametes as described by Conand (1981, 1993a). According to her studies, the five sexual stages in holothurians are stage I (immature), stage II (resting) comprise individuals of undetermined sex, stage III corresponds to the early maturation, stage IV includes mature and spawning individuals, and stage $\mathrm{V}$ is the post spawning stage. For each gonad, the tubule length from the gonad base to the distal tip was measured using a measuring tape and tubule diameter was measured through a microscope. The excised gonads spread on a slide were examined using a compound microscope. The maturity stages were recorded to determine the monthly percentage of each stage. For histological studies of the gonad, selected tubules from each stage were preserved in buffered formalin (10\%) and the standard histological method was followed to assess the maturity stages as described by Tuwo and Conand (1992) and Ramofafia et al. (2000).

Due to the absence of oocytes in indeterminate and growing stages of gonadal development, a set of selected female gonads from three different stages, i.e. maturing, mature and spent, were taken from each monthly sample for measuring the oocyte diameter. The tubules were placed separately in a beaker and were cut open to free the oocytes. The oocyte samples were placed in a counting chamber and the diameter of 30 oocytes was measured along the largest and smallest axis, using a precalibrated micrometer.

Monthly gonad index (GI) was expressed as a ratio of wet gonad weight to wet drained body weight $\times 100$, and the mean value was calculated for all females, males and 
indeterminate animals in each monthly sample as followed in the previous studies (Conand 1981, 1993b; Ramofafia et al. 2001).

For estimating fecundity, the oocyte of 10 tubules from each mature female was teased out and transferred to a measuring cylinder. After thorough mixing, a 1-ml subsample was pipetted out to a counting chamber and the number of oocytes counted. From the mean of the three samples, the average number of oocytes per tubule was calculated. The absolute fecundity (FA) was calculated by multiplying the average number of oocytes per tubule with the total number of tubules. The relative fecundity related to eviscerated weight (FrE) was calculated as FA/mean eviscerated wt (g) and FrG (fecundity related to mean gonad weight) as FA/mean ovary wt (g) (Conand 1993a, b). An index of fecundity was worked out by dividing the mean gonadal weight of the mature ovary by the mean cube diameter of the oocyte (Harriott 1985).

Since the external cues play an important role in the reproduction of holothurians (Ramofafia et al. 2000, 2001, 2003) data on rainfall, temperature and salinity were collected. Data on monthly variation in rainfall were obtained from Meteorology Department, Tuticorin Port Trust. Monthly seawater samples for temperature and salinity were collected in between two islands off Tuticorin at 10-15 m depth using Nansen's reversing water sampler. The salinity was estimated by the standard method of Strickland and Parson 1972.

Homogeneity of variance and normality of the data were tested by Cochran's test and $Z$-test. The statistical significance of relationships was assessed either by the Pearson product moment correlation and regression analysis (Sokal and Rohlf 1969), MS Excel and SPSS 7.5 programmes.

\section{Results}

Sex ratio

Of the $294 \mathrm{H}$. spinifera dissected, $38.1 \%$ were indeterminate, $32.65 \%$ were male and $29.25 \%$ were female. The observed male:female ratio of $H$. spinifera at Tuticorin was 1.1:1.0. Chi-square test revealed that the slight dominance of males was insignificant.

\section{Gonad morphology}

The gonad of $H$. spinifera was a single structure and consisted of numerous branched tubules arising from a gonad basis and attached to the anterior body wall, typical of other holothurians. The gonoduct opened externally at the gonopore, dorsally above the mouth. The mean $( \pm \mathrm{SE})$ number of tubules was $187 \pm 5(n=294)$. The males $(235 \pm 9)$ had more tubules than the females $(210 \pm 7)$, whereas the indeterminate had $136 \pm 5$. Males have significantly more tubules than the females $(t=2.98, n=294, P<0.01)$.

The five stages of gonad development based on tubule size and colour are given in Table 1. Among males, the tubule length varied from $33 \mathrm{~mm}$ (March 2001) to $51 \mathrm{~mm}$ in October 2001, whereas the females had 24 and $47 \mathrm{~mm}$ tubule length in August and April 2001, respectively (Fig. 1a). The tubule length of male was significantly greater $(t=2.537$, $P<0.05)$ than that of the females. There was no significant relationship between the total length of the animal and the length of the tubule. The tubule length was longest during the peak gametogenic period of September-November. 
Table 1 Maturity stages based on morphology and colour of gonad tubules in gametogenic stages of Holothuria spinifera

\begin{tabular}{|c|c|c|c|c|c|c|}
\hline \multirow[t]{2}{*}{ Stages } & & \multirow{2}{*}{$\begin{array}{l}\text { Mean gonad } \\
\text { weight }(\mathrm{g})\end{array}$} & \multicolumn{4}{|l|}{ Tubule } \\
\hline & & & $\begin{array}{l}\text { Mean length } \\
(\mathrm{mm})\end{array}$ & $\begin{array}{l}\text { Mean diameter } \\
(\mu \mathrm{m})\end{array}$ & $\begin{array}{l}\text { Mean saccule } \\
\text { length }(\mathrm{mm})\end{array}$ & Colour \\
\hline \multirow[t]{2}{*}{ Indeterminate } & I & $0.1 \pm 0.05$ & $9 \pm 0.1$ & $164 \pm 8$ & - & White \\
\hline & II & $0.4 \pm 0.12$ & $17 \pm 0.8$ & $255 \pm 9$ & - & White \\
\hline \multirow[t]{2}{*}{ III Maturing } & Male & $1.4 \pm 0.3$ & $33 \pm 2$ & $639 \pm 32$ & $5 \pm 0.5$ & Creamy white \\
\hline & Female & $2.1 \pm 0.5$ & $31 \pm 4$ & $802 \pm 64$ & $4 \pm 0.3$ & Yellow \\
\hline \multirow[t]{2}{*}{ IV Mature } & Male & $4.3 \pm 0.3$ & $51 \pm 2$ & $887 \pm 21$ & $8 \pm 0.9$ & Creamy white \\
\hline & Female & $5.6 \pm 0.7$ & $40 \pm 2$ & $1,022 \pm 37$ & $6 \pm 0.4$ & Dark yellow \\
\hline \multirow[t]{2}{*}{ V Spent } & Male & $0.7 \pm 0.2$ & $25 \pm 4$ & $268 \pm 28$ & - & White \\
\hline & Female & $0.4 \pm 0.1$ & $18 \pm 3$ & $309 \pm 31$ & - & White \\
\hline
\end{tabular}
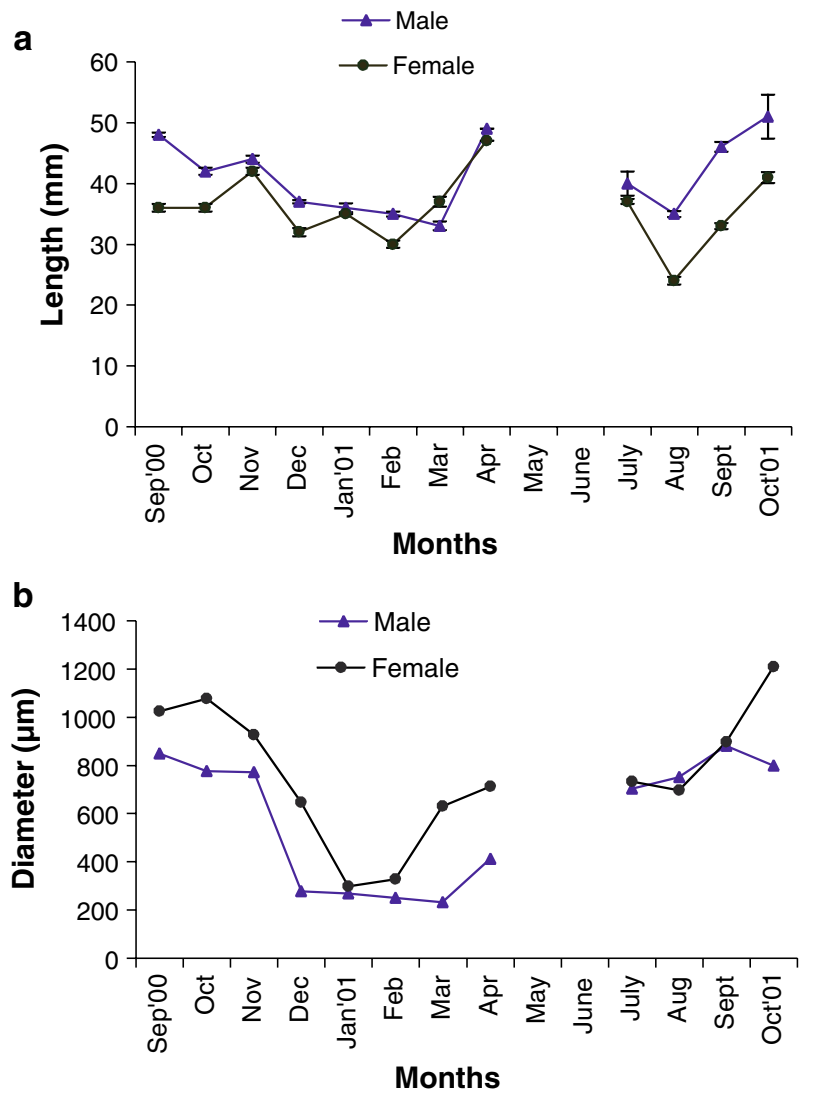

Fig. 1 a Monthly variation in tubule length and $\mathbf{b}$ diameter of Holothuria spinifera (bars are standard errors of the mean) 
Among males, the tubule diameter was highest $(882 \mu \mathrm{m})$ in September 2001 and lowest $(233 \mu \mathrm{m})$ in March 2001 (Fig. 1b). The tubule diameter ranged from 1 to $1.2 \mathrm{~mm}$ during the peak gametogenic period of September-November 2001 among females and the difference was highly significant $(t=3.921, P<0.01)$.

Histology of the gonadal tubule in $H$. spinifera revealed that the five gonad maturity stages correlated with five gametogenic developmental stages. A description of the histological features of each gametogenic stage is described below.

\section{Stage I: Immature}

Unbranched small tubules with thick body wall, only the primordial germ layer could be seen. Germinal cells were not observed inside the tubule.

\section{Stage II: Growing}

The germinal epithelium was convoluted. The primordial germ layer was visible and germinal cells were seen, but sex of the gonad could not be deciphered.

Testis development

\section{Stage III: Maturing}

The primordial germ layer developed into spermatogonia, which underwent development into spermatocytes. The secondary spermatocytes thus produced were released into the lumen of the tubes. The sperms were non-motile. The process of gamete production will continue until the entire lumen gets filled up with spermatocytes (Fig. 2a).

\section{Stage IV: Mature}

The gonad wall was at its minimal thickness. The lumen of the tubule was densely packed with active spermatozoa. The presence of a few spermatocytes was observed (Fig. 2b).

\section{Stage V: Spent}

Shrunken tubules, generally had an empty lumen except for a few relict unreleased spermatozoa (Fig. 2c).

Ovary development

\section{Stage III: Maturing}

Ovarian wall thick and oocytes did not entirely fill up the lumen. Developing oocytes connected to the ovarian stroma. Oocytes varied in diameter (modal size $50 \mu \mathrm{m}$ ), mostly circular in nature with or without nucleolus (Fig. 2d). 

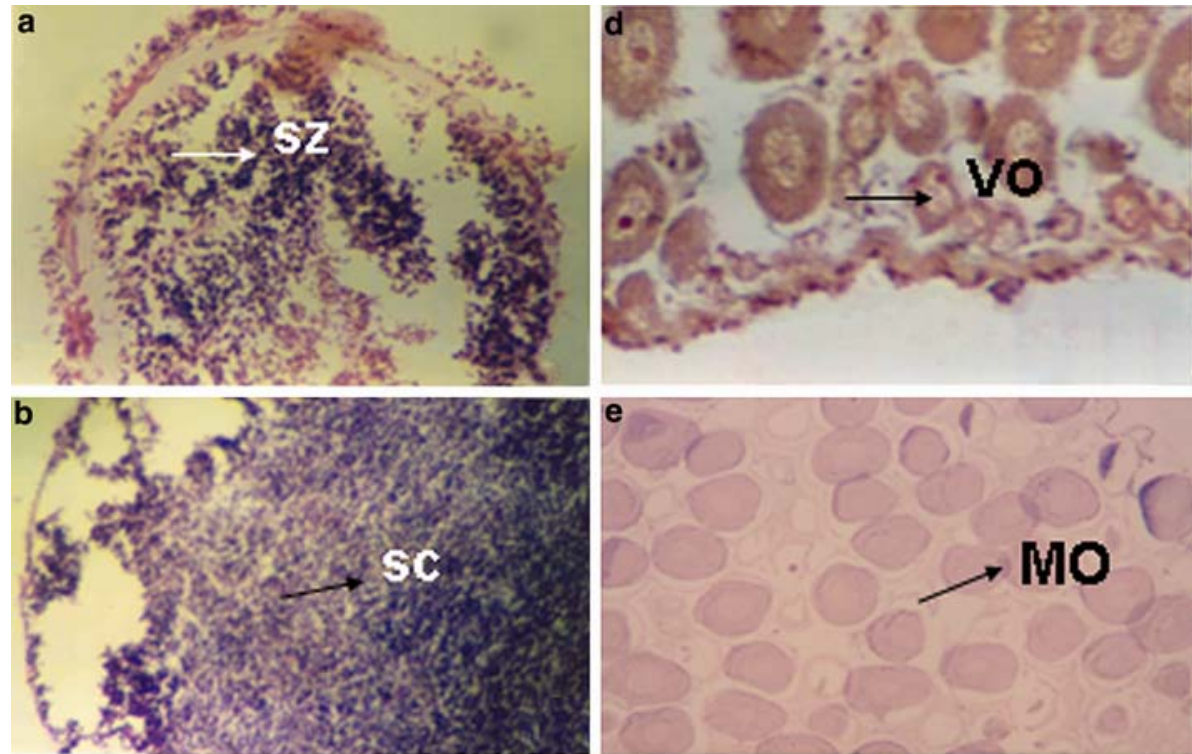

C

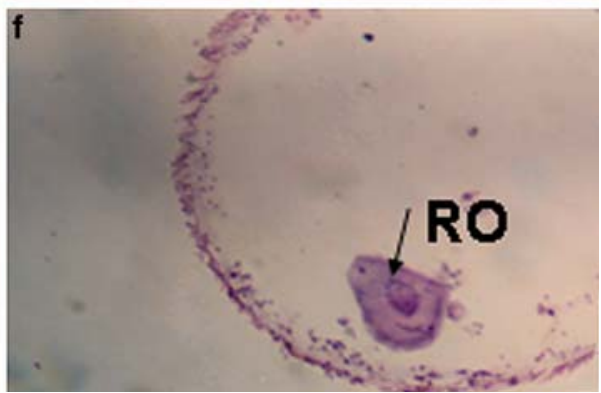

Fig. 2 Gonad histology of Holothuria spinifera. a Male maturing; b male mature; c male spent; d female maturing; e female mature; f female spent. $S Z$ Spermatozoa, $S C$ spermatocytes, $R S$ relict spermatozoa, $V O$ vitellogenic oocyte, $M O$ mature oocyte, $R O$ relict oocyte. Scale bars in a $128 \mu \mathrm{m}$; in b $118 \mu \mathrm{m}$; in c $134 \mu \mathrm{m}$; in d $160 \mu \mathrm{m}$; in e $146 \mu \mathrm{m}$; in f $61.8 \mu \mathrm{m}$ )

\section{Stage IV: Mature}

The ovarian wall was at its minimal thickness. Polymodal shaped oocytes, which were in the late vitellogenic stage, modal size $(182 \mu \mathrm{m})$, were visible through the thin transparent tubule wall; the oocytes remained within the follicle (Fig. 2e).

\section{Stage V: Spent}

Ovarian wall was thick, wrinkled and shrunken. Relict oocytes (modal size $166 \mu \mathrm{m}$ ) were occasionally present in the lumen of the tubules. Phagocytes were clearly evident (Fig. 2f). 
Maturity stages

Mature animals predominated with $100 \%$ and $76.8 \%$ during September and October 2000, respectively. Spent animals started occurring from November onwards up to March and indicated spawning activity. Presence of indeterminate alone during April to July 2001 revealed the gonadal resting phase. Again in September and October 2001, the matured animals predominated with $80.9 \%$ (Fig. 3).

Gonad index

The gonad index (GI) between sexes was variable. The value of GI for males ranged from 0.05 to 8.04 with a mean \pm SE value of $1.44 \pm 0.14$ and for females it varied from 0.013 to 8.7 ( $2 \pm 0.2$ ). Though the GI value of females was higher than those of males, the difference was not significant.

The monthly mean GI varied from 0.03 to 1.8 . During peak gonadal maturation periods of September and October 2000, high values of 1.5 and 1.54 was observed. A medium value of $0.8-0.9$ was noted during February-March 2001. The low (mean \pm SE) value of $0.03 \pm 0.041$ in May 2001 increased to $0.2 \pm 0.118$ in June and attained the high value of $1.8 \pm 1.274$ in October 2001, when the majority of the animals were mature (Fig. 4). High significance $(t=5, d f=13, P<0.01)$ was noted between the differences in GI between months.

Depending on the monthly variations of the gonad index, the tubule diameter also varied. At the low GI of 0.03 in May 2001, the tubule diameter was $240 \mu \mathrm{m}$ and at the high GI of 1.8 in October 2001 the gonad tubule diameter was greatest $(990 \mu \mathrm{m})$. A highly significant relationship $(r=0.8698, P<0.01)$ was expressed as $y=-0.0118+0.0018 x$ (where $y=$ GI and $x=$ tubule diameter) between tubule diameter and gonad index.

\section{Fecundity}

The mean number of oocyte per tubule of $H$. spinifera varied from a minimum of 2,233 during September 2000 to a maximum of 29,667 during March 2001, with a mean $\pm \mathrm{SE}$

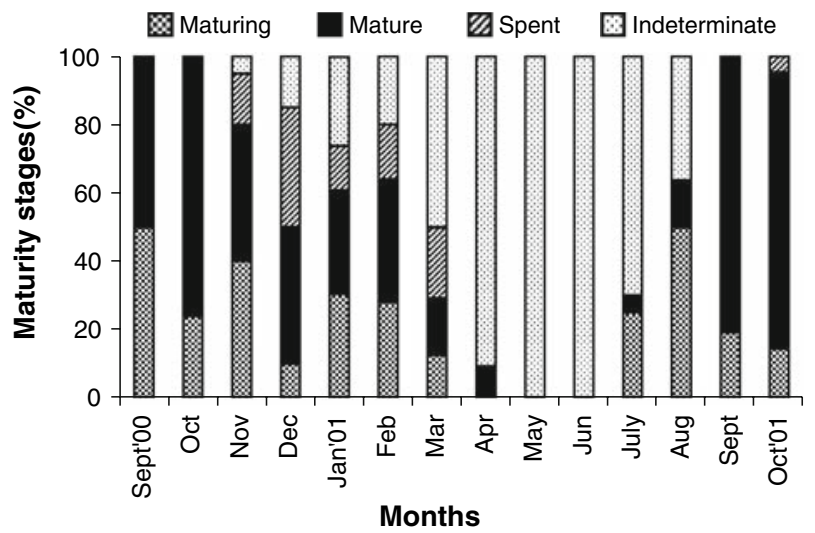

Fig. 3 Monthly percentage of maturity stages of Holothuria spinifera 
Fig. 4 Monthly variation in gonad index of Holothuria spinifera (bars are standard error of the mean)

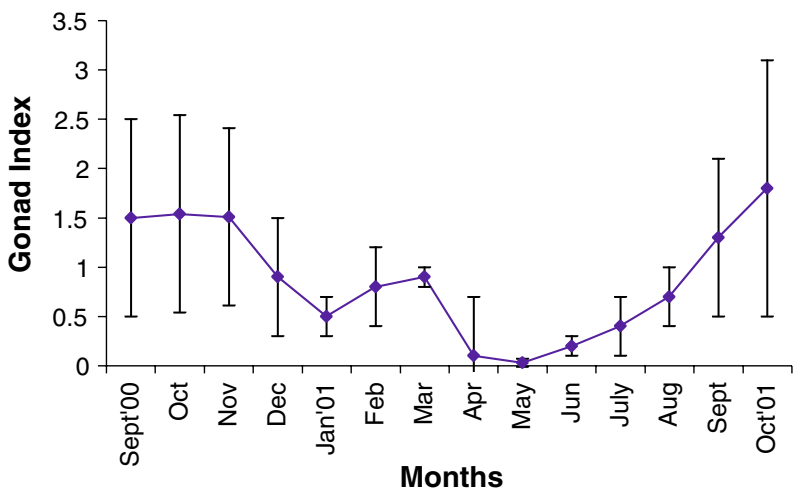

value of $7,938 \pm 697.8$. In the tubule diameter of $298 \mu \mathrm{m}$, minimum mean number of oocyte was $564 /$ tubule whereas the oocytes increased to 10,868 in the tubules having a diameter of $1.2 \mathrm{~mm}$. The relationship between these two parameters were highly significant $(r=0.923, P<0.01)$ and could be expressed by $y=-0.1468+0.4728 x$ (Fig. 5).

The absolute fecundity ranged from a minimum of $36.1\left(10^{3}\right.$ oocytes $)$ during February to $5,195\left(10^{3}\right)$ during September 2001, with a mean \pm SE value of $1,739 \pm 179\left(10^{3}\right)$, as in other holothurians.

Low relative fecundity per eviscerated weight (FrE) of 0.16 in February 2001 and a high value of 36.4 in September 2001 were observed. The mean FrE worked out to $10.8 \pm 1.1$. The relative fecundity per $\mathrm{g}$ ovary weight $(\mathrm{FrG})$ varied from 28 (in February 2001) to $899 \times 10^{3}$ (in October 2001) with the mean FrG for $H$. spinifera being $(362 \pm 31) 10^{3}$ oocytes.

During the period of high reproductive output, the calculated fecundity index was 1,799, 2,191 and 1,840 in September, October and November 2000, respectively. Intermediate levels of 1,400 and 980 were observed in February and March 2001. Again, higher indices of 1,540 and 1,510 were obtained in September and October 2001. The average fecundity index worked out to 1,770 .

At the sampling site, the water temperature varied between $28^{\circ} \mathrm{C}$ in September 2000 to $32^{\circ} \mathrm{C}$ in May 2001 and the salinity between 31 ppt in September 2000 to 37.2 ppt in June 2001. The rainfall ranged from $1.8 \mathrm{~cm}$ in September 2000 to $20.9 \mathrm{~cm}$ in November 2000 (Fig. 6). The lowest values of temperature and salinity observed were associated with the

Fig. 5 Relationship between mean number of oocytes and tubule diameter of Holothuria spinifera

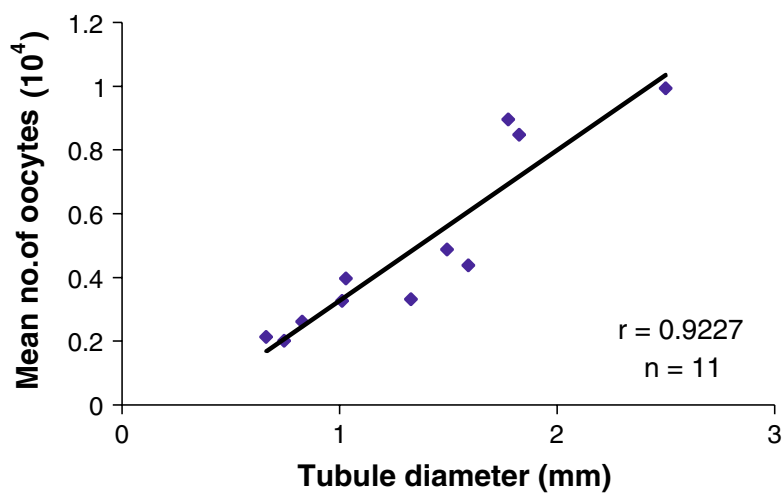


Fig. 6 Mean monthly sea surface temperature, rainfall and salinity off the Tuticorin area

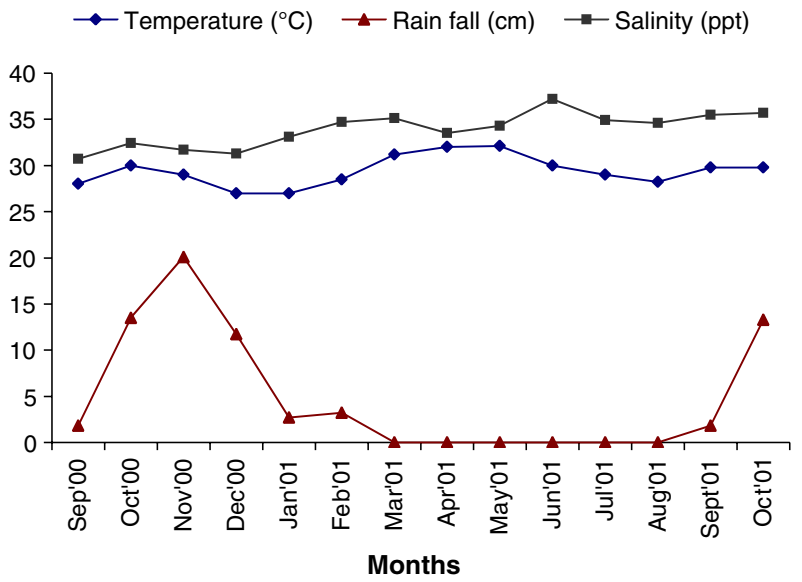

winter season and the rainfall due to the North East monsoon occurred during SeptemberFebruary. In captivity, $H$. spinifera spawned three times, the first one was spontaneous in March 2001 and the second and third spawning during December 2002 and January 2003, respectively, were by addition of powdered feed (rice bran, soya powder and Sargassum powder at 4:2:1) at the rate of $50 \mathrm{~g} / 5001$.

\section{Discussion}

The study indicated that the reproductive aspects of $H$. spinifera, such as gonochoric condition, absence of sexual dimorphism and external fertilisation, etc., are similar to most of the tropical aspidochirotes (Conand 1993a,).

The mean values of tubule length and diameter were comparatively lower than those of H. fuscogliva and H. scabra (Ramofafia et al. 2000, 2003) and almost the same as the medium-sized sea cucumbers like Stichopus variegates, presently known as Stichopus hermanni (Conand 1993b), Actinopyga mauritiana (Ramofafia et al. 2001) and Isostichopus fuscus (Herrero Perezrul et al. 1999).

The histological sections of the gonadal tubules showed the presence of gametes in both male and female gonads during post-spawning stage indicating the partial events of shedding. The thickening of the outer epithelium of the gonadal wall during the recovery stage and its subsequent reduction indicates that this may be the nutrient storage site for metabolic activity (Ramofafia et al. 2001, 2003). Stratification of spermatogonia and spermatids was not observed in the sections of the gonad of H. spinifera, similar to the observation of Morgan (2000) in H. scabra.

The phagocyted material in the spent gonad tubules was used to nurture other developing gametes (Smiley and Cloney 1985; Sewell and Bergquist 1990; Hamel et al. 1993). After spawning, the gonad of $H$. spinifera decreased in size because of phagocytosis. During gametogenesis, the germinal layer became thinner and the longitudinal folds extended into the lumen. This process, which is common in the members of the family Holothuridae, significantly increases the surface area for the development of gametes (Cameron and Fankboner 1986).

The structure of the gonad of $H$. spinifera is a single tuft of tubules, joined at the proximal end, typical of other holothurians. Males have a significantly higher number of 
tubules than the females as in other aspidochirotes (Conand 1981). The tubular diameter was greater in the female than in the male and is in agreement with the works of Foster and Hodgson (1995), who reported that the diameter of the tubules of the males was significantly smaller than that of females of Roweia stephensoni and Neostichopus grammatus.

The elongated branched gonadal tubules having characteristic saccules with uniform gamete development in the germinal epithelium is as in Thelenota ananas, T. anax and Stichopus chloronotus (Conand 1993b). The ripe female has larger gonads in stage IV indicating high reproductive output. The gonadal tubules were shorter and wider in females, as observed by Hoareau and Conand (2001).

The tubules were present throughout the year and were not absorbed after spawning. The occurrence of $H$. spinifera with indeterminate stage after breeding indicated complete rest. The reabsorption of gonad was absent in this species. Presence of phagocytes might have limited the reabsorption of gonad tubules (Hamel et al. 1993). Hence the Tubule Recruitment Model (TRM) proposed by Smiley (1988) and Tuwo and Conand (1992) could not be applicable to $H$. spinifera.

The mean diameter of the oocyte $(148 \mu \mathrm{m})$ is higher than the $88 \mu \mathrm{m}$ for $\mathrm{H}$. atra and $103 \mu \mathrm{m}$ for H. edulis (Harriott 1985), and similar to the $155 \mu \mathrm{m}$ of H. scabra, $149 \mu \mathrm{m}$ of Actinopyga echinites and $150 \mu \mathrm{m}$ for $H$. nobilis (Conand 1993b). In the aspidochirotes, the modal size of the mature oocyte varies between 150 and $210 \mu \mathrm{m}$, indicative of planktotrophic development (Conand 1993b).

The GI of female $H$. spinifera was higher than that of males, similar to Stichopus mollis (Sewell and Bergquist 1990), H. nobilis, H. fuscogliva, H. fuscopunctata, T. ananas, S. variegatus, H. scabra, H. scabra versicolor, Actinopyga miliaris, A. echinites and H. atra (Conand 1993a, b). Jayasree and Bhavanarayana (1994) also observed increased GI during September-December and again in April-May for H. leucospilota.

The maximum diameter of the gonadal tubule $(990 \mu \mathrm{m})$ was in October 2001, when the GI was 1.8 and at the minimum diameter of $240 \mu \mathrm{m}$ in May 2001, the GI was only 0.03 . Similarly, Ramofafia et al. (2003) noted greater ovarian tubule diameter corresponding to the GI peak in H. scabra.

The fecundity related to eviscerated weight (FrE) is similar to H. scabra versicolor and with respect to gonad weight $(\mathrm{FrG})$ it is close in proximity with A. mauritiana (Conand 1993b). The fecundity index of 1,770 of $H$. spinifera was intermediate when compared to those of $H$. atra $(6,600), H$. edulis $(2,000)$ and $H$. impatiens $(800)$. This may be attributed to the larger oocyte size $(168 \mu \mathrm{m})$ as Harriott (1985) observed for H. impatiens.

There was an increased value of GI during September-October 2001 and from December 2000 to March 2001 with a drop during January 2001. The maximum value of GI recorded during the maturity period, which indicated the highest gametogenic activity and the sharp decline during May-June 2001, was when the population was at the resting stage (Fig. 4). The occurrence of spent from November 2000 to March 2001 indicated the spawning period.

The breeding period of $H$. spinifera (November-March) coincided with a period of rainfall, low salinity and temperature (Fig. 6). The spawning may be due to high productivity associated with rainfall and local run-off as one among the other environmental factors, such as temperature, food availability, photoperiod and salinity on gametogenesis and spawning in holothurians, as envisaged by Himmelman (1981) Cameron and Fankboner (1986) and Krishnaswamy and Krishnan (1967). The successful induced spawning obtained in $H$. spinifera by addition of feed in the captive condition (Asha 2005) also indicated the role of feed in spawning. Similarly, Battaglene et al. (2002) also observed spawning in $H$. fuscogliva by addition of powdered algal feed. 
The gonochoric condition, gonad consisting of number of long tubules, medium size of oocyte, high fecundity and prolonged spawning period, also indicated the reproductive strategies of $H$. spinifera. Information on the morphology of gonad tubules provides the reliable character in assessing the reproductive condition of the animal. This will be of great benefit in breeding programmes as suggested by Yanagisawa (1998), Reichenbach (1999) and Ramofafia et al. (2003). In addition, these observations on the reproductive aspects and tubules will be of much use in attempting the biopsy of gonad tubules to assess the gonadal maturity stages of captive brood stock for induced spawning trials in the sea cucumber hatchery.

Acknowledgements We thank Prof (Dr.) Mohan Joseph Modayil (Director) and Dr. M.Rajagopalan (Head of the Fishery Environment and Management Division) of Central Marine Fisheries Research Institute, Kochi, for their interest and encouragement.

\section{References}

Asha PS (2005) Reproductive aspects, larval and juvenile rearing of Holothuria (Theelothuria) spinifera Theel. PhD thesis Manonmaniam Sundarnar University, TamilNadu, India, $120 \mathrm{pp}$

Battaglene SC, Seymour JE, Ramofafia C (2002) Spawning induction of three tropical sea cucumbers, Holothuria scabra, Holothuria fuscogliva and Actinopyga mauritiana. Aquaculture 207:29-47

Cameron JL, Fankboner PV (1986) Reproductive biology of the commercial sea cucumber Parastichopus californicus (Stimpson) (Echinodermata: Holothuroidea). Reproductive periodicity and spawning behavior. Can J Zool 64:168-175

Chellaram C, Samuel VD, Patterson Edward JK (2003) Status of echinoderm fishery in the Gulf of Mannar South east coast of India. SDMRI Res Publ 3:173-176

Conand C (1981) Sexual cycle of three commercially important Holothurian species (Echinodermata) from the lagoon of New Caledonia. Bull Mar Sci 31:523-543

Conand C (1993a) Ecology and reproductive biology of Stichopus variegatus and Indo-Pacific coral reef sea cucumber (Echinodermata: Holothuroidea). Bull Mar Sci 52:970-981

Conand C (1993b) Reproductive biology of the holothurians from the major communities of the New Caledonian Lagoon. Mar Biol 116:439-450

Conand C (1997) Are holothurian fisheries for export sustainable? Proc 8th Int coral Reef Symposium 2. In: Lessios HA, Macintyre I (eds) Smithsonian Tropical Research Institute, Balboa, Panama, pp 2021-2026

Foster GG, Hodgson AN (1995) Annual reproductive cycle of three sympatric species of intertidal holothurians (Echinodermata) from the coast of the Eastern Cape Province of South Africa. Invert Reprod Dev 27:49-59

Hamel JF, Himmelman JH, Dufresne L (1993) Gametogenesis and spawning of the sea cucumber Psolus fabricii (Duban and Koren). Biol Bull 184:125-143

Harriott VJ (1985) Reproductive biology of three congeneric sea cucumber species, Holothuria atra, $H$. impatiens and H. edulis at Heron Reef, Great Barrier Reef. Aust J Mar Freshwat Res 36:51-57

Herrero-Perezrul MD, Bonilla HR, Dominguez FG, Cintra Buenrostro CE, (1999) Reproduction and growth of Isostichopus fuscus (Echinodermata: Holothuroidea) in the southern Gulf of California, Mexico. Mar Biol 135:521-532

Himmelman JH (1981) Synchronization of spawning in marine invertebrates by phytoplankton. In: Clark WH Jr, Adems TS (eds) Advances in invertebrate reproduction. Elsevier, New York, pp 3-19

Hoareau T, Conand C (2001) Sexual reproduction of Stichopus chloronotus, a fissiparous sea cucumber of Reunion Island, Indian Ocean. SPC Beche-de-mer Inform Bull 15:4-12

James DB (1995) Taxonomic studies on the species of Holothuria (Linnaeus, 1767) from the seas around India. Part 2. J Bombay Nat Hist Soc 92:190-204

James DB, Badrudeen M (1997) Observation on the landings of the sea cucumber Holothuria spinifera at Rameswaram by Chanku madi. Mar Fish Info Ser 149:6-8

Jayasree V, Bhavanarayana PV (1994) Reproduction in Holothuria (Mertensiothuria) leucospilota (Brandt) from Anjuna, Goa. Bull Cent Mar Fish Res Inst 46:57-62

Krishnaswamy S, Krishnan S (1967) Report on the reproductive cycle of holothurian Holothuria scabra Jaeger. Curr Sci 36:155-156 
MPEDA (1998) Statistics of the marine products exports, 1996. The marine products exports. Development Authority, Cochin, India, $30 \mathrm{pp}$

MPEDA (2003) Statistics of the marine products exports, 2001. The marine products exports Development Authority, Cochin, India, pp 122-124

Morgan AD (2000) Aspects of the reproductive cycle of the sea cucumber Holothuria scabra (Echinodermata: Holothuroidea). Bull Mar Sci 66:47-57

Ramofafia C, Battaglene SC, Bell JD, Byrne M (2000) Reproductive biology of the commercial sea cucumber Holothuria fuscogliva in the Solomon Islands. Mar Biol 136:1045-1056

Ramofafia C, Battaglene SC, Byrne M (2001) Reproductive biology of Actinopyga mauritiana (Echinodermata: Holothuridae) in the Solomon Islands. J Mar Biol Assoc UK 81:523-531

Ramofafia C, Byrne M, Battaglene SC (2003) Reproduction of the commercial sea cucumber Holothuria scabra (Echinodermata: Holothuroidea) in the Solomon Islands. Mar Biol 142:281-288

Reichenbach N (1999) Ecology and fishery biology of Holothuria fuscoglovia (Echinodermata: Holothuroidea) in the Maldives, Indian Ocean. Bull Mar Sci 64:103-113

Sewell MA, Bergquist PR (1990) Variability in the reproductive cycle of Stichopus mollis (Echinodermata: Holothuroidea). Invert Reprod Dev 17:1-7

Smiley S (1988) The dynamics of oogenesis and the annual ovarian cycle of Stichopus californicus (Echinodermata: Holothuroidea). Biol Bull 175:79-93

Smiley S, Cloney RA (1985) Ovulation and the fine structure of the Stichopus californicus (Echinodermata: Holothuroidea) fecund ovarian tubules. Biol Bull 169:342-364

Sokal RR, Rohlf FJ (1969) Introduction to biostatistics. Freeman, San Fransisco

Strickland JDH, Parson TR (1972) A practical hand book of sea water analysis. Bull Fish Res Bd Can $167: 311$

Tuwo A, Conand C (1992) Reproductive biology of the holothuria Holothuria forskali (Echinodermata). J Mar Biol Assoc UK 72:745-758

Yanagisawa T (1998) Aspects of the biology and culture of the sea cucumber. In: De Silva SS (ed) Tropical mariculture. Academic Press, London, pp 292-308 